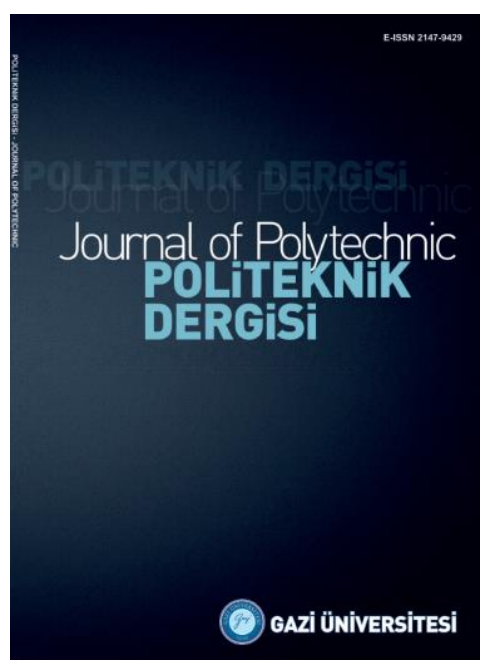

POLITEKNIK DERGISI

JOURNAL Of POLYTECHNIC

ISSN: 1302-0900 (PRINT), ISSN: 2147-9429 (ONLINE)

URL: http://dergipark.gov.tr/politeknik

\title{
Significance of concrete production in terms of carbondioxide emissions: social and environmental impacts
}

\section{Beton üretiminin karbondioksit emisyonları açısından önemi: toplumsal ve çevresel etkiler}

Yazar(lar)(Author((s)): Irem ȘANAL

ORCID: 0000-0003-1682-1789

Bu makaleye șu șekilde atıfta bulunabilirsiniz(To cite to this article): Şanal i. " Significance of concrete production in terms of carbondioxide emissions: social and environmental impacts", Politeknik Dergisi, 21(2): 369-378, (2018). 


\title{
Beton Üretiminin Karbondioksit Emisyonları Açısından Önemi: Toplumsal ve Çevresel Etkiler
}

\author{
Araştırma Makalesi / Research Article \\ İrem ŞANAL* \\ Mühendislik ve Doğa Bilimleri Fakültesi, İnşaat Müh. Bölümü, Bahçeşehir Üniversiesi, Türkiye \\ (Geliş/Received : 02.10.2016 ; Kabul/Accepted : 26.08.2017)
}

ÖZ

Beton etkili sürdürülebilir kalkınmayı destekleyen güçlü çevresel faydalarından dolayı oldukça önem kazanmakta olan bir malzemedir. otoriteler, mühendisler ve tasarımcılar, artan çevresel ve ekonomik güçlere tepki olarak yenilenemez kaynakları koruyan verimli, yenilikçi somut çözümler arayışındadırlar. Bir yapı malzemesinin ömrü üzerindeki çevresel etkisini göz önünde bulundurunca birçok açıdan- üretim, inşaat, işletme, yıkım ve geri dönüşüm - beton en avantajlı seçenektir. Dünya çapında beton üretim atıklarına bir düzenleme getirilme ihtiyacı büyümekte olan bu çevresel ve ekonomik etkiler sonucu ortaya çıkmaktadır. Özellikle son yıllarda çimento imalat sürecinde yüksek enerji tüketimini ve çevresel etkileri önemli ölçüde azaltabilen bazı alternatiflere ulaşmak için araştırmacılar tarafindan çeşitli çalışmalar yapıldığı bilinmektedir. Bu nedenle, geleneksel betonlara çevre dostu bir alternatif olarak "yeşil beton" kavramı ortaya çıkmaktadır. Bu yayın, betonun gelecek nesillerin sürdürülebilir kalkınmasına nasıl katkıda bulunduğunu ve mimar, mühendis, müteahhit ve müşterilerin yanı sıra binalarda ve altyapı tasarımında, inşasında veya işletmede yer alan diğer kişiler üzerindeki etkilerini de göstermeyi amaçlıyor. Betonun karbondioksit (CO2) emisyonuna katkıda bulunan asıl kaynakları belirlemek ve geleneksel betonları "yeşil betonlar" ile karşılaştırmak, harmanlanmış çimentolarla üretilen betonları ve çimentonun kısmen azaltılması için kullanılan uçucu külü kullanmak suretiyle beton üretiminin çevresel etkisini incelemek bu çalışmanın temel amaçlarıdır.

Anahtar Kelimeler: Karbon emisyonları, çevresel faktörler, çimento üretimi, beton üretimi, sürdürülebilirlik.

\section{Significance of Concrete Production in Terms of Carbondioxide Emissions: Social and Environmental Impacts}

\begin{abstract}
Concrete is being recognized for its strong environmental benefits in support of creative and effective sustainable development. In response to growing environmental and economic forces, regulatories, engineers, developers and owners are seeking efficient, innovative concrete solutions that conserve non-renewable resources. When considering the lifetime environmental impact of a building material -extraction, production, construction, operation, demolition and recycling-concrete is the most advantageous choice to meet these goals. Global demands for regulating concrete production waste arise from the growth of these environmental and economic issues. Various efforts have been conducted by researchers to arrive at some alternatives that are able to significantly reduce high energy consumed and environmental impacts during fabrication process of cement. Therefore, the concept of "green concrete" as an environmentally friendly alternative to conventional concrete has been emerging. This publication seeks to demonstrate how concrete contributes to future generations' sustainable development, and will be of interest to architects, engineers, policy makers, contractors and clients, as well as others involved with the design, construction or operation of buildings and infrastructure. The main objective of this study is to identify and evaluate the key sources contributing to $\mathrm{CO}_{2}$ emissions from concrete and compare traditional concretes with "green concretes", concretes produced with blended cements and fly ash used as partial replacement of cement, in order to diminish the environmental impact of the concrete production.
\end{abstract}

Keywords: Carbon emissions, environmental apects, cement production, concrete production, sustainability

\section{INTRODUCTION}

Upsurge in population, unplanned urbanization, depletion of natural sources rapidly bring environmental problems together. Construction sector is one of the leading sectors that cause environmental problems. At the present time, generally buildings are constructed by reinforced concrete framework construction technique (Aydin and Sancak 2005).Concrete is a basic building

\footnotetext{
*Sorumlu yazar (Corresponding Author)
}

e-posta : irem.sanal@eng.bau.edu.tr material that will continue to be in demand far into the future. A world without concrete, and its dominant precursor, Ordinary Portland Cement (OPC), is hard to imagine. Although there are different types of concrete that have been developed for use in different applications, their common virtues are familiarity, versatility, strength, durability, wide availability, fire resistance, resistance to the elements and comparatively low cost. Global concrete industry uses approximately 1.6 billion tonnes of cement and 10 billion tonnes of sand, gravel, and crushed rock every year (Mehta, 2001). The 
world's yearly cement production of 1.6 billion tonnes accounts for about $7 \%$ of the global loading of carbon dioxide $\left(\mathrm{CO}_{2}\right)$ into the atmosphere (Mehta, 2001).There are two major sources of greenhouse gas (GHG) emissions associated with concrete production: (a) The mining, processing, and transport operations involving large quantities of aggregate consume considerable amounts of energy, produce large quantities of GHGs, and adversely affect the ecology of the areas they are extracted from. As the hauling distances between the quarries to the processing plants and processing plants to construction sites increase, GHG emissions associated with the transportation of NA also increase. (b) The manufacturing of cement involves emission of considerable amount of GHG in the atmosphere. It is estimated that producing one tonne of Portland cement requires about four giga-joules of energy, which in turn emits 1.25 tonnes of carbon dioxide into atmosphere (Wilson, 1993).

\section{1. $\mathrm{CO}_{2}$ Emissions of Concrete Industry}

The push to reduce global $\mathrm{CO}_{2}$ emissions is backed by governments and corporations who understand that the present rate of release of GHG into the atmosphere is a serious threat to future life and prosperity on the planet. Various authorities have introduced legislation and incentives (tax rises such as $\mathrm{CO}_{2}$ taxes, quarrying and extraction tax, etc.) in order to regulate and reduce the activities of the industrial sectors most responsible for greenhouse gas emissions. However, the rate of increase in emissions continues almost unabated as a result of population growth and increased industrialization and economic activity in developing countries. (OECD/IEA and World Business Council for Sustainable Development, 2009). Regardless of personal feelings about global warming, carbon emissions, LEED certifications, or any "green" terms, it is important to realize our decisions have consequences, and our actions can make a difference in the future. cement formulations and production processes are needed.

Due to concrete's large consumption, even small reductions of greenhouse gas emissions per ton of manufactured concrete can make a significant global impact. Therefore, reliable estimates of $\mathrm{CO}_{2}$ emissions of various construction materials are becoming important, because of the environmental awareness of the users. The $\mathrm{CO}_{2}$ emissions from most of the activities involved in concrete production and placement result from the energy consumed to accomplish them. Hence, to find the $\mathrm{CO}_{2}$ emissions associated with an activity, the energy consumption per unit of material produced had to be audited. Examples of carbon footprint of concrete and concrete structures are given, taking into account the embodied energy during all the life cycle phases (Figure 1).

Several studies have been carried out on cement, concrete and concrete products that have pointed out phases of its life cycle that have a major environmental impact ( Boesch and Hellweg, 2009; Huntzinger and Eatmon, 2010; Boesch and Hellweg, 2010; Young et al., 2002; Ali et al, 2011; Kim and Worrell, 2012; Lundström, 1997; Van Geem, 1998; Nisbet and Van Geem, 1997). Although the final product of all cement plants is more or less of the same quality, significant differences of raw materials (e.g., fuel consumption), production processes and varying performance/investments in air pollution control systems lead to different environmental impacts. Portland cement is not environmentally very friendly material. Previous research into the environmental impacts of cement production has already yielded several estimates of the $\mathrm{CO}_{2}$ emissions per tonne of cement produced. Similarly, fly ash and GGBFS have also both been investigated previously, and their emissions quantified.

In terms of embodied $\mathrm{CO}_{2}$ during the production phases, concrete will have significant carbon footprint, in which

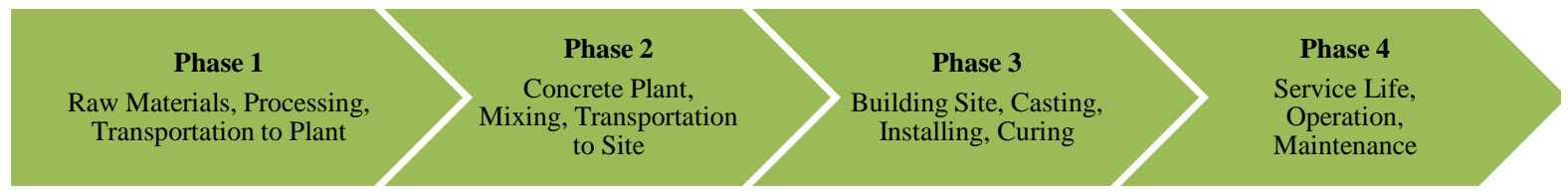

Figure 1. Life cycle phases from cradle to grave.

It seems safe to say we all want to preserve or improve our environment, and we want our children and our grandchildren to have a better environment than we enjoy. As practitioners in our industry, more steps should be taken in order to make a difference. If the cement and concrete industries are to become sustainable and effectively contribute to emission reduction then, in addition to improvements in process efficiency and reliance on ordinary Portland cement (OPC) blends incorporating waste materials, moving to less carbon intensive fuels, developing clinker substitutions employing other low carbon materials with cementitious properties, and new low carbon and carbonreducing the main contributor is the cement manufacturing process. Other cementitious components considered include ground granulated blast furnace slag (GGBFS), a by-product of the steel industry, and fly ash, a by-product of burning coal. These two materials are generally used to replace a portion of the cement in a concrete mix. The use of water and admixtures in concrete leads to minimal $\mathrm{CO}_{2}$ emissions, which leaves cement, coarse and fine aggregates as the main material contributors to the environmental impacts of concrete. Clinker production is the most energy-intensive stage in cement production, accounting for over $90 \%$ of total energy use, and virtually all of the fuel use. Therefore, more blended cements or 
cement replacement, especially with chemical and mineral admixtures should be used.

In the present paper, $\mathrm{CO}_{2}$ emission results from production of concretes with both ordinary Portland cement, blended cement and fly ash/slag replacement is examined. The necessary data for the elaboration of this paper came mainly from ready-mix concrete production plants located in Turkey, but other sources of data are used where necessary in order to figure out necessary assumptions (IPCC, 2006).

\subsection{Sustainable Green Concretes}

Concrete has shaped civilizations from as far back as Ancient Egypt and the Greek and Roman Empires. Today, it is indispensable in the development of infrastructure, industry and housing. Without concrete, the built environment would fail to accommodate the modern and demanding lifestyles.

To be truly sustainable, all aspects associated with a concrete structure, including design, location, materials utilized, construction techniques, maintenance, impact on the environment, overall energy consumption, and effect on future generations must be considered. All elements should be coordinated in a manner to benefit society. The consequences of today's decisions now will definitely affect our environment and society in the future. Much of the concern in the field of going green relates to carbon emissions in the atmosphere. A reported threefold increase in $\mathrm{CO}_{2}$ in the atmosphere since 1977 prompts the global warming concern. One aspect of sustainability is the minimization or elimination of carbon emissions to reduce the portion of climate change that may be caused by this phenomenon.

When it comes to building structures, developers and contractors have the advantage of choosing from a variety of materials to use. Generally, the decision on material choice depends on several factors including cost and performance for specific applications. Due to growing interest in sustainable development and various incentives, the key players in the construction industry are motivated more than ever before to use materials that are sustainable or in such a way that their environmental impact is minimal. $\mathrm{CO}_{2}$ emissions from cement manufacturing contribute significantly to global warming. To mitigate those effects, researchers are exploring how advanced materials and nanotechnologies can produce 'greener' concretes that are environmentallyfriendly, and just as durable.

Therefore, it is important to develop green concrete that can be used in buildings and structures. Green concrete is defined as a concrete which uses waste material as at least one of its components; or its production process does not lead to environmental destruction. In other words, green concrete is an environment friendly concrete. Green concrete improves the three pillars of sustainability: environmental, economic, and social impacts. The key factors that are used to identify whether the concrete is green are amount of portland cement replacement materials, manufacturing process and methods, performance and life cycle sustainability impacts. Materials used for making green concrete are composed of renewable, rather than non-renewable resources. These materials are refereed to as green materials and are environmentally responsible because impacts are considered over the life of the product. Depending upon project-specific goals, green materials may involve an evaluation of the three criteria given in the following:

(i) Locally available: Construction materials, components, and systems found locally or regionally, saving energy and resources in transportation to the project site.

(ii) Salvaged, re-furnished, or re-manufactured: Includes saving a material from disposal and renovating, repairing, restoring, or generally improving the appearance, performance, quality, functionality, or value of a product.

(iii) Reusable or recyclable: Select materials that can be easily dismantled and reused or recycled at the end of their useful life.

Various efforts have been conducted by researchers to arrive at some alternatives that are able to significantly reduce high energy consumed and environmental impacts during fabrication process of cement, including implementing the concept of industrial ecology and green chemistry as well as nanoengineering that study the behavior of the structure and organization of nanoparticles of cement in the mix for achieving higher performance. The philosophy of green concrete, in fact of any green product is based on the principle of optimizing its embodied energy i.e. on minimizing the energy spent to put it into its final functional form. It therefore depends on the practices related to every stage of its production. How green a product is generally defined, depending on the embodied energy, since the lower the embodied energy is, the greener the product will be. For concrete, any practice which aids to reduce the energy associated with its production, energy efficient cement production, use of blended cements, savings made on transportation of ingredients and direct use of recycled waste contribute towards its greenness.

There are a number of alternative environmental requirements with which green concrete structures must comply:

- $\mathrm{CO}_{2}$ emissions shall be reduced by at least $30 \%$.

- At least $20 \%$ of the concrete shall be residual products used as aggregate.

- Use of concrete industries own residual products.

- Use of new types of residual products, previously land filled or disposed of in other ways.

- $\mathrm{CO}_{2}$-neutral, waste-derived fuels shall substitute fossil fuels in the cement production by at least 10 $\%$.

\subsection{Alternative Ways of Making Green Concretes}

The concrete industry is dedicated to continuous environmental improvement through process and product 
innovation. One important issue is the use of environmental-friendly concrete "green concrete" to enable world-wide infrastructure-growth without increase in CO2- emission. The key findings of this study are the emissions associated to the various components of both traditional and green concretes and how they consolidate into a carbon footprint for concrete.

\subsubsection{Blended cements}

The production of blended cements involves the intergrinding of clinker with one or more additives; e.g. fly ash, bnb granulated blast furnace slag, silica fume, volcanic ash, in various proportions. The use of blended cements is a particularly attractive efficiency option since the intergrinding of clinker with other additives not only allows for a reduction in the energy used (and reduced GHG emissions) in clinker production, but also directly corresponds to a reduction in $\mathrm{CO}_{2}$ emissions in calcinations as well. Blended cement has been used for many decades around the world [Worrell \& Galtisky 2004]. Although it is most common to make use of supplementary cementing materials in the replacement of cement in the concrete mixture, blended cement is produced at the grinding stage of cement production where fly ash, blast furnace slag, or silica fume are added to the cement itself.

Blast furnace slag (GGBS) is a by-product of iron manufacturing industry. The production of GGBS requires little additional energy compared with the energy required for the production of Portland cement. Blended Portland cement with GGBS will lead to a significant reduction of $\mathrm{CO}_{2}$ gas emission. GGBS is therefore an environmentally friendly construction material. It can be used to replace as much as $80 \%$ of the Portland cement when used in concrete. GGBS concrete has better water impermeability characteristics as well as improved resistance to corrosion and sulphate attack. As a result, the service life of a structure is enhanced and the maintenance cost reduced. High volume eco-friendly replacement slag leads to the development of concrete which not only utilizes the industrial wastes but also saves significant natural resources and energy. This in turn reduces the consumption of cement.

\subsubsection{Cement Replacement}

Reuse of post-consumer wastes and industrial byproducts in concrete is necessary to produce even "greener" concrete. A great potential exists to reduce the concrete industry's contributions to greenhouse gases through reductions in cement consumption. One alternative concrete system is the use of fly ash as a supplementary cementing material.

Fly ash is produced from coal and some other solid fuel combustion systems, where bottom fuel ash is left in the region of combustion, fine grained fly ash is carried with combustion flu gases and commonly collected by electrostatic precipitation. Because of its pozzolanic properties, fly ash is often used to replace typically $30 \%$ of the mass of Portland cement in a concrete mix, for example to lower permeability and reduce initial heat evolution. Fly ash will contribute to the strength of concrete after seven days of curing. Strength development of fly ash in concrete is due to a chemical reaction between the fly ash and calcium hydroxides.

\subsection{Environmental Significance of Concrete}

The extensive use of green concretes with cement replacement of fly ash in the construction industry has a number of environmental benefits. These benefits can be classified as longer service life, recycled material usage, reduced energy consumption, reduced $\mathrm{CO}_{2}$ emissions. Longer Service Life: Green concrete gains strength faster and has a lower rate of shrinkage than concrete made only from Portland Cement. Structures built using green concrete have a higher resistance to fire. It also has a greater resistance to corrosion, which is important with the effect pollution has had on the environment. Acid rain greatly reduces the longevity of traditional building materials. All of those factors add up to a building that will last much longer than one made with ordinary concrete. Similar concrete mixtures have been found in ancient Roman structures. If buildings aren't constantly having to be rebuilt, fewer construction materials are needed. The impact on the environment is reduced. Uses Industrial Waste: In view of the energy and greenhouse gas (GHG) emission concerns in the manufacturing of portland cement, it is imperative that either new environmentally friendly cement-manufacturing technologies be developed or substitute materials be found to replace a major part of the portland cement for use in the concrete industry [Malhotra 2004]. Instead of a $100 \%$ Portland cement mixture, green concrete uses between $25 \%$ and $100 \%$ fly ash. Fly ash is a byproduct of coal combustion. It is gathered from the chimneys of industrial plants that use coal as a power source. There are copious amounts of this industrial waste product. Hundreds of thousands of acres of land are used to dispose of fly ash. Green concrete provides a way to use fly ash and save many acres of land.

Reduced Energy Consumption: If you use less Portland cement and more fly ash when mixing concrete, then you will use less energy. The materials that are used in Portland cement require huge amounts of coal or natural gas to heat. Fly ash already exists as a byproduct of another industrial process, so you are not expending much more energy to use it to create green concrete. Another way that green concrete reduces energy consumption is that a building constructed from it is more resistant to temperature changes, thus saving heating and cooling costs.

Reduced $\mathrm{CO}_{2}$ Emissions: Among the main ingredients in ordinary cement are pulverized limestone, clay, and sand which are heated to a high temperature. This process is responsible for between 5 and $8 \%$ of all $\mathrm{CO}_{2}$ emissions worldwide. The manufacturing of green concrete releases up to $80 \%$ fewer Carbon Dioxide emissions. As a part of a global effort to reduce emissions, switching completely to green concrete for construction will help considerably. 


\subsection{Social Significance of Concretes}

Major forces that were responsible for economic and social transformations in society are population growth, industrialization and urbanization, globalization of market economy and consumerism, and environmental pollution. The forces are interconnected. Their combined impact has triggered another force, namely climate change, which is threatening to cause serious damage to human civilization on the earth. Global warming is the most important sustainability issue today in the public mind.

In recent years, the focus was put on environmental aspects when addressing the question of sustainable development and construction. The social and economic aspects of sustainability have been almost ignored, which has created a distorted working definition of sustainability. Conservation and environmental protection has become a major world issue in the global context. Since The World Earth Summit 1997 in Kyoto, Japan, which initiated the need to reduce $\mathrm{CO}_{2}$ emissions on a large scale (targeted before 2010 emissions reduced by about $21 \%$ ) to avoid catastrophic global world, so many huge industrial countries around the world have agreed to formulate regulations that dreams related to the mission of the protection and preservation of the environment can become a reality. (Malhotra, 1999) About $8 \sim 10 \%$ of total world $\mathrm{CO}_{2}$ emissions, which are believed to be the main drivers of global climate change did not come from polluting vehicles on the highway or a forest fire, but comes from the cement manufacturing process in cement factories. Global warming gas is released when the raw material of cement, limestone and clay is crushed and heated in a furnace at high temperature $( \pm 15000 \mathrm{C})$. Each year, approximately 1.89 billion tons of cement (which is a major component of concrete) have been produced worldwide.

In addition to strive for minimal environmental impact during the use cycle of concrete (since the process of making cement, concrete manufacture until, for example 50 years, concrete buildings that have been used dismantled / broken), which is no less important aspect in the success of efforts to conserve the environment are: government policies/institutions/ industries through various forms of regulation, the willingness of the user community, and (the willingness of the industry itself to change the perception. Cement and concrete industries that have grown rapidly and established, may have to change the situation due to issues of preservation and protection of the environment, due to a significant change from how concrete is designed, specified, manufactured, transported, printed, finished, and recycled money (Holland, 2002). To illustrate that during the service life cycle use of concrete / concrete experience various stages that need to be considered in all aspects of conservation / environmental protection.

\section{MATERIAL and METHOD}

The objective of this study is to identify the key emission sources contributing to the GHG emissions from concrete. Following this it will be possible to quantify the emissions resulting from the production of a cubic meter of concrete. These calculations can then be extrapolated to depict the emissions resulting on a national level as well as in the various sectors of end use. The final, logical objective is to evaluate possible mitigation strategies to decrease the $\mathrm{CO}_{2}$ emissions from concrete production.

\subsection{Identification and Determination of Emissions}

The first step that is required before emission sources can be identified is to select a reporting boundary, where there are three main scopes of emissions that will need to be examined within each activity:

- Scope1 - Direct emissions: Primarily result from on site consumption of fossil fuels.

- Scope 2 - Indirect emissions: The main GHG emission source results from the electricity consumption.

- Scope 3 - Other Indirect emissions: Final production transportation and outsourced activities

Since concrete is a product composing of a number of components with each component contributing to the overall emissions related to concrete production, the services and materials included in the production process of concrete have been identified and depicted in Table 1 .

Table 1. Identification of emission sources according to the corresponding activity

\begin{tabular}{|c|c|c|c|}
\hline \multirow[b]{2}{*}{ Activity } & \multicolumn{3}{|c|}{ Emission Sources } \\
\hline & 1.Direct & 2.Indirect & 3.Other Indirect \\
\hline \multirow[t]{4}{*}{ Cement } & $\begin{array}{c}\text { Coal Firing } \\
\text { of Kiln }\end{array}$ & \multirow{4}{*}{ Electricity } & \multirow{4}{*}{$\begin{array}{c}\text { Transportation } \\
\text { to site } \\
\text { Water } \\
\text { Consumption } \\
\text { Landfill Usage }\end{array}$} \\
\hline & $\begin{array}{c}\text { On site } \\
\text { Fuel-Kiln }\end{array}$ & & \\
\hline & $\begin{array}{c}\text { Calcination } \\
\text { of Raw } \\
\text { Materials }\end{array}$ & & \\
\hline & $\begin{array}{c}\text { On Site } \\
\text { Fuel- } \\
\text { Vehicles }\end{array}$ & & \\
\hline \multirow[t]{2}{*}{$\begin{array}{l}\text { Aggrega } \\
\text { tes }\end{array}$} & $\begin{array}{l}\text { On Site } \\
\text { Fuel- } \\
\text { Vehicles }\end{array}$ & \multirow[t]{2}{*}{ Electricity } & $\begin{array}{c}\text { Transportation } \\
\text { to site } \\
\text { Water }\end{array}$ \\
\hline & Explosives & & Consumption \\
\hline Fly Ash & $\begin{array}{c}\text { On Site } \\
\text { Fuel- } \\
\text { Vehicles }\end{array}$ & & $\begin{array}{l}\text { Transportation } \\
\text { to site }\end{array}$ \\
\hline Slag & $\begin{array}{l}\text { On Site } \\
\text { Fuel- } \\
\text { Vehicles }\end{array}$ & & $\begin{array}{l}\text { Transportation } \\
\text { to site }\end{array}$ \\
\hline $\begin{array}{l}\text { Admixt } \\
\text { ures }\end{array}$ & $\begin{array}{c}\text { On Site } \\
\text { Fuel- } \\
\text { Vehicles }\end{array}$ & & $\begin{array}{l}\text { Transportation } \\
\text { to site }\end{array}$ \\
\hline $\begin{array}{l}\text { Readym } \\
\text { ix }\end{array}$ & $\begin{array}{c}\text { On Site } \\
\text { Fuel-Loader }\end{array}$ & & $\begin{array}{c}\text { Transportation } \\
\text { to site } \\
\text { Water } \\
\text { Consumption } \\
\text { Landfill Usage }\end{array}$ \\
\hline
\end{tabular}




\subsection{Emissions from the Concrete Production}

Water, sand, stone or gravel, and other ingredients make up about $90 \%$ of the concrete mixture by weight. The process of mining sand and gravel, crushing stone, combining the materials in a concrete plant and transporting concrete to the construction site requires very little energy and therefore only emits a relatively small amount of $\mathrm{CO}_{2}$ into the atmosphere. The amounts of $\mathrm{CO}_{2}$ embodied in concrete are primarily a function of the cement content in the mix designs.
Emissions resulting from fly ash are mainly from direct emissions, since the bulk of emissions result from diesel use in on site trucks. Fly ash is the by-product of the power industry. Therefore, the specific emissions only took activities into consideration post "primary" production. The major emissions associated with fly ash preparation is from electricity consumption. Just like fly ash, the product would be produced regardless of demand from the concrete and cement industries. The largest direct emissions source results from fuel used for on site

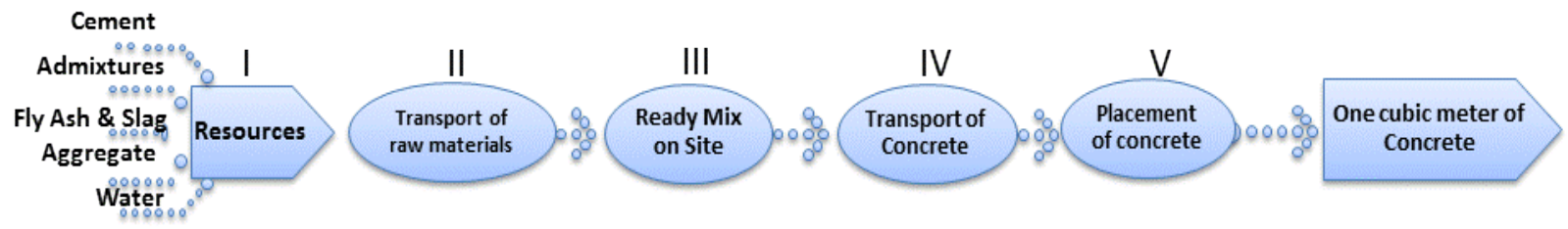

Figure 2 Concrete $\mathrm{CO}_{2}$ emissions system diagram (Adapted from: Flower and Sanjayan, 2007, p238).

All of these sources from I to $\mathrm{V}$ will count towards a concrete production activity's $\mathrm{CO} 2$ emissions inventory. In the scope of this study, only the sources I, II, III and IV will be examined and included in the $\mathrm{CO}_{2}$ emission calculations, since the emissions related with concrete placement and service life will be the scope of a further study, which will be the 2nd part of the present research.

\subsubsection{Emissions from Cement}

Cement has received the most attention out of all of the components that contribute to concrete and has been comprehensively scrutinised (Humphreys and Mahasenan, 2002). This is due to the fact that it has a relatively high specific emission and is produced in large quantities. The main indirect emissions source is grid electricity consumption, since cement sites are large energy intensive industrial sites (Hendriks et al., 1998; Humphreys and Mahasenan, 2002).Main other indirect emissions result from off-site transport of raw or intermediate products by road, rail and trucks. Transport does not normally have a significant impact on the total $\mathrm{CO} 2$ emissions of cement production due to the large quantity of emissions from direct and indirect sources (Worrell et al., 2001).

\subsubsection{Emissions from Aggregates}

There are very few emissions resulting from aggregate production, which include explosives for the blasting of geological reserves and fuel used by onsite vehicles; mainly for loading and hauling, as well as electricity contributing to indirect emissions. Indirect emissions account for up to $70 \%$ of emissions from aggregate production, which is due to crushing operations at a quarry rely on electricity.

Diesel usage accounts for most of the Scope 1 emissions. The bulk of Scope 2 emissions come from the consumption electricity. Due to the fact that explosives are consumed in such small amounts there are very few emissions associated to explosives despite their high specific emissions.

\subsubsection{Emissions from Fly Ash and Slag}

vehicles. The emission factor for the fly ash and slag manufacturing are taken based on a previous study (Flower and Sanjayan, 2007).

\subsubsection{Emissions from Admixtures}

Admixture manufacturers were not able to supply their related emissions and hence internal literature sources were used for these specific emissions. The primary emission sources from admixtures are from fuel and electricity. Plasticisers are usually added in concentrations of 0.25 to $0.8 \%$ by weight of cement. Therefore, admixtures have a small contribution to the footprint of concrete due to the fact that they are used in very small quantities per cubic meter of concrete. The emission factor for the admixture manufacturing for different types of admixtures are adapted from a previous study (Flower and Sanjayan, 2007).

\subsubsection{Emissions from Water}

Water consumption contributed the least $\mathrm{CO}_{2}$ emissions to a cubic meter of concrete. Other similar studies that were examined excluded these components which contribute less that one half of a percent of $\mathrm{CO}_{2}$ emissions to a cubic meter. The investigation of emissions associated with water consumption revealed they could in fact be deemed as immaterial.

\subsubsection{Emissions from Readymix Concrete Production}

The emissions resulting from the processes involved in the preparation of readymix will be very low. This is due to the fact that the processes are not energy intensive. Readymix sites produce the concrete mix and transport it to site. It is expected that emissions will result primarily from fuel use, followed by emissions from electricity.

\subsubsection{Emissions from Concrete Transportartion to Site}

The transport of batched concrete consumes diesel fuel. Through trucking records taken over one year period, the average amount of fuel consumed per cubic metre of concrete transported was found to be $3.11 / \mathrm{m}^{3}$, which was 
found to be responsible for $0.009 \mathrm{t} \mathrm{CO} 2-\mathrm{e} / \mathrm{m} 3$. According to the National Academy of Science (USA), the fuel consumptions of light and heavy vehicle, concrete trucks' average fuel consumption is $2,9 \mathrm{~km} / \mathrm{l}$. Therefore, the specific fuel consumption for a concrete truck operated is calculated as $0,19 \mathrm{kgCO} 2 / \mathrm{km} \cdot \mathrm{m}^{3}$ (based on 2,6 kg-CO2/lt emission). The calculation of $\mathrm{CO}_{2}$ emissions can be obtained through calculations from production data or through direct measurement.

\section{CALCULATIONS}

Direct measurement of emissions is almost always impractical, so the $\mathrm{CO}_{2}$ emissions resulting from concrete production was investigated using closed ended questionnaires distributed to readymixed concrete plants and manufacturers of cement, aggregates, fly ash and admixtures.

\subsection{Emission Factors}

Questions were designed to gather specific activity data covering all emission sources from 6 readymix concrete plants, sites located across Ankara and Istanbul establish the emissions per cubic meter of a specific concrete mix. An appropriate measurement of emissions intensity needed to be selected. In the case of the concrete industry, measurement of emissions intensity format was chosen to be "t $\mathrm{CO}_{2}$ emitted per cubic meter of concrete produced" ( $\left.\mathrm{t} \mathrm{CO}_{2} / \mathrm{m}^{3}\right)$. The data were gathered by means of questionnaires were then consolidated and inputted into the model to determine the associated $\mathrm{CO}_{2}$ emissions. This was done by linking the activity data with an emissions factor (Table 2), and resulting specific emissions of $\mathrm{CO}_{2}$ per $\mathrm{m}^{3}$ of each emission source were obtained for each component of the concrete industry. The figures obtained were then totalled and divided by the total product produced to determine an emission factor (Table 3)

\section{RESULTS AND DISCUSSION}

\subsection{Emissions Related with Concrete Production}

For comparative purposes various mix designs from 6 different readymix concrete plants are given below. It is important to note that, concrete produced in Site 1 is

Table 2. Emission Factors (IPCC, 2006) ( NRMCA, 2012)

\begin{tabular}{|l|}
\hline Source \\
\hline Diesel Fuel Consumption \\
\hline Consumption of Electricity \\
\hline Water Consumption on Site \\
\hline Landfill Usage \\
\hline Average Transport Distance- Diesel Tracks \\
\hline
\end{tabular}

contributing to the concrete industry. Some of the sources include fuel and electricity consumption as well as total raw product sold. Additionally, default emissions factors were used and inferential methodologies to determine the $\mathrm{CO}_{2}$ emissions were applied. Each of the activities of the concrete industry had a tailored questionnaire, based on average monthly: i)Production amounts $\left(\mathrm{m}^{3}\right)$, ii)Electricity Consumption $\left(\mathrm{kWh} / \mathrm{m}^{3}\right)$, iii) Fuel Consumption $\left(1 \mathrm{t} / \mathrm{m}^{3}\right)$, iv)Plant Water Consumption $\left(\mathrm{kg} / \mathrm{m}^{3}\right)$, v)Landfill Usage (hectare), vi)Transport Distance $(\mathrm{km})$. The most common sources for emission factors are the IPCC and the GHG. Typical emission factors include the following examples in Table 2, taken from the IPCC and other references. (IPCC, 2006) ( NRMCA, 2012)The emission factors obtained were then inputted into a concrete $\mathrm{CO}_{2}$ determination model to

\section{Emission Factor}

2,697

0,866

0,009

0,9

0,19

\begin{tabular}{|c|c|}
\hline Unit & Scope \\
\hline $\mathrm{kgCO}_{2} / \mathrm{lt}$ & 1 \\
\hline $\mathrm{kgCO}_{2} / \mathrm{kWh}$ & 2 \\
\hline $\mathrm{kgCO}_{2} / \mathrm{lt}$ & 3 \\
\hline $\mathrm{kgCO}_{2} / \mathrm{ha}$ & 3 \\
\hline $\mathrm{kgCO}_{2} / \mathrm{km}$ & 3 \\
\hline
\end{tabular}

green concrete with silicafume and fly ash replacement. Additionally, concretes from Sites 2, 3 and 4 are also green concretes with blended cements as can be seen in Table 4.

Table 4. Type of Concretes from Different Sites

\begin{tabular}{ccc}
\hline Site & $\begin{array}{c}\text { Concrete } \\
\text { Class }\end{array}$ & Type of Application \\
\hline $\mathbf{1}$ & Green & Cement Replacement \\
\hline $\mathbf{2 , 3 , 4}$ & Green & Blended Cement \\
\hline $\mathbf{5 , 6}$ & Normal & - \\
\hline
\end{tabular}

The emissions associated with each activity in the concrete production process were combined into a total figure based on mix design, which were given in Table 5.

Table 3. Emission Factors Calculated for each component of the concrete

\begin{tabular}{|c|c|c|}
\hline Activity & Emission Factor & Unit \\
\hline CEM I & 0,913 & $(\mathrm{t} \mathrm{CO} 2 / \mathrm{t})$ \\
\hline CEM III/B & 0,350 & $(\mathrm{t} \mathrm{CO} 2 / \mathrm{t})$ \\
\hline Aggregate & $0,009-0,05^{*}$ & $(\mathrm{t} \mathrm{CO} 2 / \mathrm{t})$ \\
\hline Fly Ash & 0,027 & $(\mathrm{t} \mathrm{CO} 2 / \mathrm{t})$ \\
\hline Slag & 0,143 & $(\mathrm{t} \mathrm{CO} 2 / \mathrm{t})$ \\
\hline Admixture & $0,04-0,05 *$ & $(\mathrm{t} \mathrm{CO} 2 / \mathrm{t})$ \\
\hline Water & 0,009 & $(\mathrm{t} \mathrm{CO} 2 / \mathrm{t})$ \\
\hline Concrete Batching & $0,09-0,015^{*}$ & $(\mathrm{t} \mathrm{CO} 2 / \mathrm{m} 3)$ \\
\hline *Can be different according to the specific type of material used \\
\hline
\end{tabular}


Figure 3 compares the $\mathrm{CO}_{2}$ variations between the designed mixes from 6 different plants. Dependent on the concrete mix proportions, the range of total $\mathrm{CO}_{2}$ emissions (including Scope 1, 2 \&3) were calculated between 0,271 (Site 4) and 0,443 (Site 5) t CO2/m3, as can be seen in Figure 3. It is also observed from Figure 3 that concrete mixtures with $\mathrm{Cem}$ III/B cement (Site 2, 3 and 4) has the lowest $\mathrm{CO}_{2}$ emissions, whereas mixtures with CEM I (Site 1, 5 and 6) showed higher $\mathrm{CO}_{2}$ emissions. Considering the mixtures with same type of cement (CEM I), it can be noted that whenever a mineral admixture is used (Site 1) the emissions resulting from concrete production are decreased (when compared to Site 5 and 6). Due to the fact that cement has a relatively large emissions factor small changes in content result in significant $\mathrm{CO}_{2}$ variations.

Additionally, from Figure 3 it was observed that, for traditional concrete mistures (Site 5 and Site 6), change in concrete type (C35 and C45) does not have a significant effect on the resulting carbon emissions. cement and concrete industry has fully committed to the need for sustainable development. Efficiencies and innovations during concrete manufacturing, along with its inherent properties in a range of applications, ensure that green concrete provides solutions to the built environment that help to achieve sustainable development. The concrete industry is dedicated to continuous environmental improvement through process and product innovation. Concrete performs well when compared to other building materials but when it comes to sustainable development there is always opportunity for improvement. A sustainable industrial growth will influence the cement and concrete industry in many respects as the construction industry has significant environmental impacts due to high consumption of energy and other resources. One important issue is the use of environmental-friendly concrete "green concrete" to enable world-wide infrastructure-growth without increase in $\mathrm{CO}_{2}$ - emission. The key findings of this study are the emissions associated to the various components

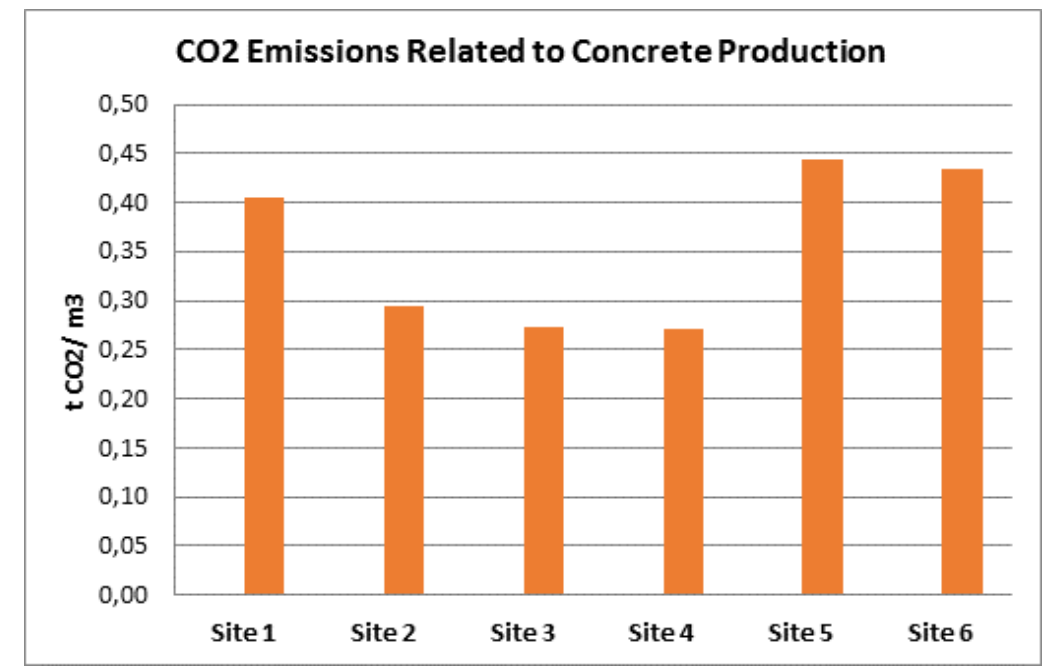

Figure 3. $\mathrm{CO} 2$ emissions resulting from various mix designs from 6 different plants

Another important point to emphasize is that, concrete mixtures from Site 1, 2, 3 and 4 are high performance (Durabet) concretes, which have higher durability and longer service lifes.

Therefore, if overall emissions throuhgout the life-cycle of concretes were to be evaluated, resulting $\mathrm{CO}_{2}$ emissions from high performance concrete's might have been decreased due to their longer lifespans. However, $\mathrm{CO}_{2}$ emissions resulting from placement, performance and service life of the concretes will not be evaluated in the scope of this study. Second part of this study will focus on the remaining sources of concrete lifecycle.

\section{CONCLUSION}

Important strategies that include social andenvironmental solutions within a detailed and comprehensive approach are required to ensure that future generations are not disadvantaged by current consumption patterns. Recognising the importance of immediate action, the of both traditional and green concretes and how they consolidate into a carbon footprint for concrete. According to the results of this study, concrete production, transport and placement activities were all found to contribute very small amounts of $\mathrm{CO} 2$ to total concrete emissions. Emission contributions due to admixtures and water were found to be negligible, whereas cement production was found to be the primary source of $\mathrm{CO} 2$ emissions. When considering green concretes, it was observed that there is a significant decrease in the $\mathrm{CO} 2$ emissions when compared to traditional concretes. Using a blended cement with GGBS results significantly lowered values of $\mathrm{CO} 2$ emissions. Based on the results, to reduce $\mathrm{CO} 2$ emissions related to concrete production, decreasing amount of cements and using fly ash as cement replacement has a significant effect on the decrease of $\mathrm{CO} 2$ emissions, since they both could potentially reduce overall energy consumption in concrete production, and this will contribute to the efforts for reducing $\mathrm{CO} 2$ emissions. 
Overall, "green concrete" has the benefits of lowered cement/CO2 footprint per unit of concrete produced. Additionally, green concrete also has potential for commercialization by providing developers and contractors with an alternative concrete that is environmental-friendly, in line with the environmental policy incentives. related to concrete production, decreasing amount of cements and using fly ash as cement replacement has a significant effect on the decrease of $\mathrm{CO} 2$ emissions, since they both could potentially reduce overall energy consumption in concrete production, and this will contribute to the efforts for reducing $\mathrm{CO} 2$ emissions.

Overall, "green concrete" has the benefits of lowered

Table 5. Resulting Carbon Emissions Based on Concrete Mix Proportions

\begin{tabular}{|c|c|c|c|c|c|c|c|c|c|c|c|c|c|}
\hline \multirow{3}{*}{ Material } & \multirow{3}{*}{ Type } & \multicolumn{12}{|c|}{ Mix Proportions and Resulting CO2 Emissions } \\
\hline & & \multicolumn{2}{|c|}{ Site 1} & \multicolumn{2}{|c|}{ Site 2} & \multicolumn{2}{|c|}{ Site 3} & \multicolumn{2}{|c|}{ Site 4} & \multicolumn{2}{|c|}{ Site 5} & \multicolumn{2}{|c|}{ Site 6} \\
\hline & & $t / m 3$ & tcO2/m3 & $t / m 3$ & tcO2/m3 & $t / m 3$ & tcO2/m3 & $t / m 3$ & $t \mathrm{co} 2 / \mathrm{m} 3$ & $t / m 3$ & $\mathrm{tCO} 2 / \mathrm{m} 3$ & $t / m 3$ & $\mathrm{tcO} / \mathrm{m} 3$ \\
\hline Cement 1 & CEMI $42,5 \mathrm{~N}$ & 0,285 & 0,260 & & & & & & & & & & \\
\hline Cement 2 & CEM III/B 32,5 & & & 0,400 & 0,140 & 0,380 & 0,133 & 0,390 & 0,137 & & & & \\
\hline Cement 3 & CEMI 42.5 R & & & & & & & & & 0,390 & 0,356 & & \\
\hline Cement 4 & CEMI 42.5 R & & & & & & & & & & & 0,310 & 0,283 \\
\hline Mineral Adm. 1 & Silica & 0,030 & 0,004 & & & & & & & & & & \\
\hline Mineral Adm. 2 & FA & 0,050 & 0,001 & & & & & & & & & & \\
\hline Agregate 1 & $0-5 \mathrm{~mm}$ & & & 0,479 & 0,043 & & & & & & & & \\
\hline Agregate 2 & 5-15 mm & & & 0,468 & 0,042 & & & & & & & & \\
\hline Agregate 3 & $15-22 \mathrm{~mm}$ & & & 0,462 & 0,041 & & & & & & & & \\
\hline Agregate 4 & $0-3 \mathrm{~mm}$ & & & 0,448 & 0,027 & & & & & & & & \\
\hline Agregate 5 & $0-3 \mathrm{~mm}$ & & & & & 0,426 & 0,051 & & & & & & \\
\hline Agregate 6 & $0-5 \mathrm{~mm}$ & & & & & 0,474 & 0,028 & & & & & & \\
\hline Agregate 7 & $5-15 \mathrm{~mm}$ & & & & & 0,496 & 0,030 & & & & & & \\
\hline Agregate 8 & $15-22 \mathrm{~mm}$ & & & & & 0,496 & 0,030 & & & & & & \\
\hline Agregate 9 & $0-5 \mathrm{~mm}$ & 0,402 & 0,026 & & & & & 0,458 & 0,029 & & & & \\
\hline Agregate 10 & $5-15 \mathrm{~mm}$ & 0,514 & 0,033 & & & & & 0,493 & 0,032 & & & & \\
\hline Agregate 11 & $15-22 \mathrm{~mm}$ & 0,495 & 0,032 & & & & & 0,423 & 0,027 & & & & \\
\hline Agregate 12 & $0-2 \mathrm{~mm}$ & 0,469 & 0,048 & & & & & 0,434 & 0,045 & & & & \\
\hline Agregate 13 & $0-5 \mathrm{~mm}$ & & & & & & & & & 0,948 & 0,045 & & \\
\hline Agregate 14 & $5-15 \mathrm{~mm}$ & & & & & & & & & 0,322 & 0,015 & & \\
\hline Agregate 15 & $15-22 \mathrm{~mm}$ & & & & & & & & & 0,546 & 0,026 & & \\
\hline Agregate 16 & $0-5 \mathrm{~mm}$ & & & & & & & & & & & 1,000 & 0,102 \\
\hline Agregate 17 & $5-15 \mathrm{~mm}$ & & & & & & & & & & & 0,408 & 0,024 \\
\hline Agregate 18 & $15-22 \mathrm{~mm}$ & & & & & & & & & & & 0,423 & 0,025 \\
\hline Admixture 1 & Optima 100 & & & 0,006 & 0,001 & 0,005 & 0,000 & 0,007 & 0,001 & & & & \\
\hline Admixture 4 & AirG100 & & & & & & & 0,001 & 0,000 & & & & \\
\hline Admixture 5 & 3587 & & & & & & & & & & & 0,003 & 0,000 \\
\hline Admixture 6 & G 675 & & & & & & & & & 0,004 & 0,000 & & \\
\hline Water 1 & Well & 0,102 & 0,001 & & & & & & & & & & \\
\hline Water 2 & Well & & & 0,148 & 0,001 & & & 0,137 & 0,001 & & & & \\
\hline Water 3 & Well & & & & & 0,141 & 0,001 & & & & & & \\
\hline Water 4 & Well & & & & & & & & & 0,161 & 0,001 & & \\
\hline Water 5 & Well & & & & & & & & & & & 0,180 & 0,002 \\
\hline
\end{tabular}

use of environmental-friendly concrete "green concrete" to enable world-wide infrastructure-growth without increase in $\mathrm{CO}_{2}$ - emission. The key findings of this study are the emissions associated to the various components of both traditional and green concretes and how they consolidate into a carbon footprint for concrete. According to the results of this study, concrete production, transport and placement activities were all found to contribute very small amounts of $\mathrm{CO} 2$ to total concrete emissions. Emission contributions due to admixtures and water were found to be negligible, whereas cement production was found to be the primary source of $\mathrm{CO} 2$ emissions. When considering green concretes, it was observed that there is a significant decrease in the $\mathrm{CO} 2$ emissions when compared to traditional concretes. Using a blended cement with GGBS results significantly lowered values of $\mathrm{CO} 2$ emissions. Based on the results, to reduce $\mathrm{CO} 2$ emissions
cement/CO2 footprint per unit of concrete produced. Additionally, green concrete also has potential for commercialization by providing developers and contractors with an alternative concrete that is environmental-friendly, in line with the environmental policy incentives.

\section{ACKNOWLEDGEMENT}

In the scope of this study, the author would like to convey special thanks to the OYAK Ready Mix Concrete plants for sharing their data generously.

\section{REFERENCES}

[1] Ali M.B, Saidur R., Hossain M.S. "A review on emission analysis in cement industries". Renew Sust Energ Rev 2011; 15 (5): 2252-2261. (2011) 
[2] Aydın, A. B. ve Sancak, E., "The Environmental Impacts of Concrete and Concrete Products", 1st International Vocational and Technical Education Technologies Congress - MTET 2005, Marmara University, Istanbul. (2005)

[3] Boesch M. E., Hellweg S. "Model for cradle-to-grate life cycle assessment of clinker production". Environ Sci Technol 2009; 43: 7578-7583. (2009)

[4] Boesch M. E., Hellweg S. "Identifying improvement potentials in cement production with life cycle assessment". Environ Sci Technol 2010; 44: 9143-9149. (2010)

[5] European Cement Association, Sited in: WWF: A blueprint for a climate friendly cement industry. (2004)

[6] Flower DJM, Sanjayan JG "Green House Gas Emissions due to Concrete Manufacture". Int J LCA 12 (5) 282 288. (2007)

[7] Hendriks, C.A., Worrell, E., Price, L., Martin, N., Ozawa Meida, L., de Jager, D. and Riemer, P. "Emission reduction of greenhouse gases from the cement industry", Proc. Fourth International Conference on Greenhouse Gas Control Technologies, August 30-September 2, Interlaken. (1998)

[8] Holland, T.C. "Sustainability of the Concrete Industry What Should be ACI,s Role". Concrete International. Vol.24, No. 7, July, 35-40. (2002)

[9] Humphreys K, Mahasenan M "Toward a Sustainable Cement Industry. Substudy 8, Climate Change". World Business Council for Sustainable Development. (2002)

[10] Huntzinger D. N., Eatmon T. D. “A life-cycle assessment of Portland cement manufacturing: comparing the traditional process with alternative technologies". $\boldsymbol{J}$ Clean Prod ; 17: 668-675. (2009)

[11] IPCC Guidelines for National Greenhouse Gas Inventories, Vol. II, Chapter 1.IPCC. (2006)

[12] Kim, Y., Worrell, E. "CO2 emission trends in the cement industry: an international comparison" Mitig Adapt Strat $\boldsymbol{G l}, 7$, pp. 115-133. (2002)

[13] Leese, R. and Casey, D. "Report on Embodied CO2e of UK cement, additions and cementitious material- Fact Sheet 18", Mineral Products Association, MPA Cement, London, UK. (2015)
[14] Lippiatt, B. C. and Ahmad, S., "Measuring the Life-Cycle Environmental and Economic Performance of Concrete : The BEES Approach." Proceedings of International Workshop on Sustainable Development and Concrete Technology, pp.213-230.(2004)

[15] Lundström, H. "LCA av Betongtakpannor - en Analys av Miljöbelastning Under Takpannans Livscykel", Chalmers Industriteknik, Göteborg, Sweden (in Swedish). (1997)

[16] Malhotra, V. M. "Making Concrete Greener with Fly Ash”. Concrete International. 21 (5), May 61-66. (1999)

[17] Mehta, P.K. "Reducing the environmental impact of concrete". Concrete International, ACI, October issue, pp: 61-66. (2001)

[18] National Research Council, “Technologies and Approaches to Reducing the Fuel Consumption of Medium and Heavy-Duty Vehicles", The National Academy of Sciences, March, pp. 2- 2 and 2-3.( 2010)

[19] Neville, A.M. "Properties of Concrete", John Wiley \& Sons. (1996)

[20] Nisbet M. and van Geem, M. "Environmental life cycle inventory of Portland cement and concrete", World Cement, Vol. 28, No. 4, pp.100-103. (1997)

[21] NRMA, National Ready Mixed Concrete Association, “Concrete CO2 Fact Sheet”, (2012)

[22] VanGeem, M. "The portland cement association's environmental life cycle assessment of concrete", Air and Waste Management Association's 91st Annual Meeting and Exhibition, San Diego, California, USA, June 1418. (1998)

[23] Wilson, A. "Cement and Concrete: Environmental Considerations", Environmental Building News, Vol. 2, No.2. (1993)

[24] Worrell, E., Price, L., Martin, N., Hendriks, C. and Ozawa Meida, L. "Carbon dioxide emissions from the global cement industry", Annual Review Energy Environment, Vol. 26, pp.303-329. (2001)

[25] Young, S., Turnbull, S. and Russell, A. "Toward a sustainable cement industry. Substudy 6 - what LCA can tell us about the cement industry", An Independent Study Commissioned by the World Business Council for Sustainable Development, (2002) 